\title{
Valuing water quality improvements from peatland restoration: Evidence and challenges
}

\author{
Julia Martin-Ortega ${ }^{\mathrm{a}, *}$, Timothy E.H. Allott ${ }^{\mathrm{b}}$, Klaus Glenk ${ }^{\mathrm{c}}$, Marije Schaafsma ${ }^{\mathrm{d}, \mathrm{e}}$ \\ a Social, Economic and Geographical Sciences Group, The James Hutton Institute, Craigiebuckler, Aberdeen AB15 8QH, United Kingdom \\ ${ }^{\mathrm{b}}$ Department of Geography, The University of Manchester, Manchester M13 9PL, United Kingdom \\ ${ }^{\mathrm{c}}$ Land Economy, Environment and Society Group, Scotland's Rural College (SRUC), Edinburgh EH9 3JG, United Kingdom \\ d CSERGE, School of Environmental Sciences, University of East Anglia, Norwich NR4 7TJ, United Kingdom \\ e Geography Department, University of Cambridge, United Kingdom
}

\section{A R T I C L E I N F O}

\section{Article history:}

Received 16 January 2013

Received in revised form

19 June 2014

Accepted 28 June 2014

Available online 8 August 2014

Keywords:

Non-market values

Blanket raised bogs

Ecosystem services

Water Framework Directive

\begin{abstract}
A B S T R A C T
There is evidence that damaged peatlands can negatively affect the delivery of water related ecosystem services. There is interest in peatland restoration to meet different regulatory targets, including the Water Framework Directive (WFD). A comprehensive assessment of the economic benefits of restoration is missing. This paper synthesises hydrological and bio-geochemical knowledge on peatland restoration, as well as insights in the monetary valuation of water quality improvements in freshwater systems. This is used to identify challenges in valuing water quality related benefits from peatland restoration. The paper concludes that there is strong evidence for rapid ecological responses to peatland restoration related to reduced suspended sediment loads, and sufficient evidence that re-wetting will prevent further decline in water quality. Two main challenges arise for valuation: (1) incomplete evidence of effects of restoration on final ecosystem services and benefits, and (2) the spatial and temporal differences in peatlands' responses. We suggest developing valuation scenarios on a case-by-case basis, using best available evidence of the changes associated with restoration described by a categorization of peatland status similar to the ecological status ladders developed for the WFD. These would need to be tested with the public and should include an element of uncertainty in services provision.
\end{abstract}

(c) 2014 Elsevier B.V. All rights reserved.

\section{Introduction}

The hydrological cycle provides society with ecosystem services that are critical to human well-being (Acreman, 2001), and that are now threatened globally by different pressures acting upon ecosystems (Millennium Ecosystem Assessment, 2005; Maltby and Ormerod, 2011). Peatland ecosystems specifically are under pressure from drainage, burning, overgrazing and agricultural expansion, and there is now evidence that damaged peatlands can negatively and chronically affect the delivery of water related ecosystem services (Bonn et al., 2010; Van der Wal et al., 2011). For example, in the UK, the Commission of Enquiry on Peatlands concluded that business as usual in relation to the status of peatland ecosystems will result in increased water quality deterioration (Bain et al., 2011).

As described by Reed et al. (2014a), there is a growing interest in peatland restoration to meet different regulatory

\footnotetext{
*Corresponding author. Tel.: +44 1224395288.

E-mail address: julia.martinortega@hutton.ac.uk (J. Martin-Ortega).
}

targets. In relation to water, this relates to the Water Framework Directive (Directive 2000/60/EC; WFD) and its target to achieve 'good ecological status' in European water bodies (Janssen et al., 2005; Ramchunder et al., 2009; Trepel, 2010; Hirst et al., 2012). Peatland restoration is also relevant for meeting drinking water requirements (e.g. Wallage et al., 2006; United Utilities, 2010) and, more generally, in relation to policies and instruments to improve or sustain ecosystem services provision (UK NEA, 2011; Bonn et al., 2014).

As explained by Glenk et al. (2014), from an economic efficiency point of view, the main question regarding peatland restoration is whether restoring peatlands increases overall social welfare. A comprehensive assessment of the economic benefits derived from restoration action is necessary to compare the benefits with the costs of restoration. This assessment is currently hindered by the lack of knowledge on economic benefits of water related services provided by peatlands. Among the few existing economic studies, some focus on the role of peatland management in mitigating climate change (Drake et al., 2013; Wichtmann and Wichmann, 2011) and others on the value for landscape amenity and wildlife conservation in peaty environments 
(White and Lovett, 1999; Strange et al., 2007; Black et al., 2010). However, we are not aware of any studies that value water related services provided by peatlands.

Recent scientific progress on understanding the biophysical impacts of peatland management on the water environment can provide an improved grounding for the valuation of water quality related services delivered by peatland ecosystems. This paper synthesises state-of-the-art hydrological and bio-geochemical knowledge in relation to peatland restoration, as well as recent economic insights in the monetary valuation of water quality improvements in freshwater systems. We identify key challenges in valuing water quality related benefits from peatland systems, with the purpose of helping to set a research agenda ultimately aimed at providing sound economic information as a basis for decision-making regarding peatland restoration.

Like the rest of this special section, this paper uses the UK as its geographical focus. We use the term peatland to encompass peatcovered terrain (sensu Rydin and Jeglum, 2006), where peat is the remains of plants accumulating under more or less water-saturated conditions due to incomplete decomposition. Blanket and raised bog peatlands cover around $23,000 \mathrm{~km}^{2}$ or $9.5 \%$ of the UK land area. Blanket bogs are by some margin the most extensive wetland type in the country, representing over 90\% of its peatland area (Bain et al., 2011). UK peatlands provide an interesting case study through which to consider the valuation of services arising from hydrological restoration, given the wide range of threats they are (or have been) exposed to. Moreover, UK peatland ecosystems have great national importance for drinking water: around $70 \%$ of the country's drinking water is derived from upland catchments, mostly dominated by peaty soils (Van der Wal et al., 2011). However, most of the issues discussed in this paper are applicable to other peatlands internationally.

\section{Evidence of relationships between blanket peatlands and water quality}

The quality of surface waters in the streams and rivers draining blanket peatlands is heavily influenced by peatland processes, and changes in the hydrological, geomorphological and ecological state of peatlands can impact water quality. This section reviews evidence from the natural sciences literature of the impacts of peat degradation and peatland restoration on water quality.

\subsection{Peat degradation and water quality}

It has been estimated that less than $20 \%$ of blanket bog in the UK is in natural or near-natural condition (Bain et al., 2011) and large areas of blanket bog have been degraded by erosion, drainage or afforestation. The erosion of blanket peatlands is commonplace in the UK and takes two forms; extensive gully development which extends dendritic gully networks and causes exposed, bare peat on the gully floors and walls, and sheet erosion which results in large exposed areas of bare peat flats (Evans and Warburton, 2007). Drainage of blanket peatlands for agriculture and afforestation is also widespread, typically taking the form of open cut drains (ditches) designed to increase peat drainage and lower water tables (Holden et al., 2004). In fact, both gully erosion and drainage by ditching lower peatland water tables, increasing rates of aerobic decomposition and reducing peat accumulation (Holden et al., 2004; Evans and Warburton, 2007).

There is clear evidence, briefly reviewed here, that peat degradation by erosion or drainage results in reduced water quality. Blanket peat degradation affects the acidity of upland freshwaters, metal concentrations, DOC and colour, and the concentration of suspended sediments or fine particulate organic matter (FPOM). Intact, accumulating peats reduce atmospherically deposited reactive nitrogen (by denitrification) and store atmospherically deposited sulphur, metals and persistent organic pollutants (e.g. Daniels et al., 2008; Rothwell et al., 2010), preventing the leaching of these into drainage waters. The water quality of drainage waters from intact peatlands is therefore buffered from atmospheric pollutants and their associated effects on surface water acidification in headwater systems, with benefits for downstream water quality and aquatic ecosystems. However, these biochemical processes are altered by lowering of water tables associated with peat erosion or drainage. For example, Clarke et al. (2005) established a clear link between episodes of water table drawdown (lowering) associated with drought, sulphate release and the acidity of peatland drainage waters. Daniels et al. (2008, 2012) show that long-term water table drawdown in a gullied peatland reduced sulphur, nitrate and ammonia retention and enhanced surface water acidification. Water table drawdown can also result in the mobilization of metals stored in peats, transforming peatlands from sinks to sources of toxic metals such as lead and arsenic (Rothwell et al., 2010). Links between acidification and elevated metal concentrations and freshwater biota are well established (see Steinberg and Wright, 1994), including impacts on invertebrate and fish populations (particularly salmonids).

Blanket peats also influence water quality through the release of dissolved organic carbon (DOC) produced by the decomposition of organic matter under aerobic conditions. Peatland systems naturally produce coloured drainage water, but comparisons of drained with intact systems consistently report higher concentrations of DOC and colour in drained peatlands where water tables have been lowered (e.g. Wallage et al., 2006; Armstrong et al., 2010). Water colour is a key water quality concern for drinking water utilities due to treatment costs.

In addition to the biochemical effects of water table drawdown, peat degradation also impacts water quality through the physical process of sediment mobilization and transport. Peat degradation through sheet erosion of peat flats, gullying and ditching exposes bare peat surfaces to surface water and stream water flow. This results in higher concentrations of FPOM and sediment loads in streams draining eroded or ditched peatlands (Evans et al., 2006; Evans and Warburton, 2007; Holden et al., 2007). FPOM has a direct impact on freshwater ecosystems through deposition on benthic habitats and reduction of species diversity (e.g. Ramchunder et al., 2012), but also has indirect effects through, for example, increased metal loadings on downstream waters through the transport of metal contaminated sediments (e.g. Rothwell et al., 2008).

\subsection{Blanket peat restoration and water quality}

Over the past decade there has been a significant increase in the number of large-scale projects to restore areas of degraded blanket peatlands (Evans et al., 2014) and a variety of techniques have been developed to carry out restoration (Parry et al., 2014). In peatlands impacted by drainage and ditches (grips), restoration has taken the form of ditch blocking, typically through the use of peat dams to block and seal the ditches and divert water flow onto the peatlands. In areas of peatland severely affected by erosion and gullying, such as the South Pennines, peat restoration projects have focused firstly on the re-vegetation of areas of bare peat to stabilize erosion and secondly on blocking erosion gullies (Anderson et al., 2009). Gully blocking methods use wooden or stone dams that do not completely fill the gully or directly divert flow onto the peatland, but are instead designed to raise local water tables and form focal points in the gullies for sedimentation, gully infilling and re-vegetation.

Monitoring data are increasingly available to evaluate the impacts of restoration practice on drainage water quality. However, 
such studies are often limited by the length of time since restoration occurred, which in many cases is less than 5 years. The strongest evidence of water quality benefits from peatland restoration comes from the significant and rapid reductions in the suspended sediment and FPOM concentrations and fluxes in upland streams and downstream drainage following restoration. The re-vegetation of eroded peat effectively shuts down sources of suspended sediments in peatland systems. Within 5 years of initial treatment suspended sediment and FPOM concentrations in restored systems are an order of magnitude lower than those in eroding peat catchments and are comparable with FPOM concentrations in intact systems (Evans et al., 2009). Similarly, reductions in stream water benthic FPOM concentrations have been observed after the blocking of drains, both from comparisons of intact, drained and blocked catchments (Holden et al., 2007) and from direct monitoring pre- and postrestoration (e.g. Wilson et al., 2011). Importantly, these improvements in sediment status of drainage systems result in rapid benefits for stream biodiversity (Ramchunder et al., 2012).

Evidence for the long-term effects of restoration on water colour and DOC, and on other dissolved pollutants such as metals and acidity, is less secure. This is partly because of a lack of longterm monitored data from restored systems, and partly because of short-term transient effects of restoration on water quality. If aerobic decomposition is the primary control on DOC production and release, then peat re-wetting by restoration should result in long-term (i.e. $>5$ years) declines in DOC and colour. Indeed, an increasing evidence base reports reductions in DOC and water colour following ditch blocking (e.g. Wallage et al., 2006; Armstrong et al., 2010; Anderson et al., 2011). However, some studies have reported no change or even increased DOC loss following blocking (e.g. Worrall et al., 2007; Gibson et al., 2009), and so there is a lack of consistent behaviour between systems. Processes of DOC production and transport are complex (e.g. Clarke et al., 2010). Long-term DOC responses to re-wetting are also potentially complicated by temporary short-term adjustment effects influencing monitoring data, which means that long ( $>5$ years) timescales are needed to adequately assess the response of the peatland to restoration activities. For example, Worrall et al. (2007) report increased DOC concentrations in the 2 years following ditch blocking which may have resulted from temporary 'flushing' of accumulated DOC following raised water tables. The short-term increases in DOC concentrations observed in this study may not therefore be representative of longer term trends at the site. It is also important to note that long-term DOC trends will be modified by other long-term drivers such as trends in acid deposition (Monteith et al., 2007) and more complex specific site factors. For example, Daniels et al. (2008) suggest that catchments in the South Pennines with very significant stores of atmospherically deposited sulphur may actually show increases in stream water DOC in response to peat re-wetting. This is due to rewetting in these systems leading to reduction of sulphate to sulphur and a decrease in acidity, which would in turn increase DOC solubility and thus stream water DOC concentrations. Perhaps surprisingly given the dominant control of atmospheric pollution and acidification on upland water quality over the last few decades, there have been limited reports of the impacts of restoration on surface water acidity, sulphate, nitrate and metal concentrations. Consistently higher water tables should reduce the oxidation of sulphur and nitrogen, reducing acidity and also having the effect of reducing the release of metal species such as zinc. DOC is also a key vector for metals such as lead and copper, so reduced colour would similarly reduce concentrations of these metals from contaminated peatlands. However, such trends have not yet been confirmed by empirical study.

In summary, there is clear evidence that peat restoration leads to rapid ( $<5$ years) improvements in particulate water quality (i.e. suspended sediments and FPOM) with associated effects on the aquatic ecosystem and biota, particularly in highly degraded systems. The timescales and magnitude of water quality improvements following peat restoration associated with dissolved pollutants (e.g. DOC, acidity, metals) are less well established, although the current weight of evidence suggests there will be long-term benefits for $\mathrm{DOC} /$ colour and metal concentrations. A further important uncertainty concerns potential regional differences in response, for example between areas which have experienced different historical loadings of acid deposition. Current understanding indicates that the timing and nature of water quality response to restoration could vary significantly depending on such factors, but the current evidence base is not wide enough to fully quantify these differences.

\section{Policy relevance of the valuation of benefits from peatland restoration}

The positive environmental impacts of peatland restoration discussed above can contribute to policy targets laid out in the WFD. The WFD requires Member States to prevent deterioration and to improve the ecological conditions of aquatic ecosystems with the aim of achieving 'good ecological status'. The UK classification system for good ecological status incorporates a number of elements which are sensitive to the water quality issues, including benthic invertebrates, fish, phytoplankton (diatoms), $\mathrm{pH}$ (for acidification) and specified pollutants including the metals zinc, copper and arsenic (UKTAG, 2007). Unequivocal attribution of peat degradation as a cause of failure to achieve the good ecological status is difficult in UK river systems, as the monitoring stations used for classification are overwhelmingly $>10 \mathrm{~km}$ downstream of the headwaters and water quality is therefore influenced by additional factors. Nevertheless, in river catchments with significant peatland degradation there is evidence of poor water quality leading to failure to achieve good ecological status consistent with the processes outlined in Section 2. In the Peak District region, for example, the rivers Ashop, Alport and Westend drain areas where peat erosion and degradation have been extensive (Evans et al., 2006). These rivers have not met good ecological status requirements due to low scores on combined $\mathrm{pH}$ and fish indicators and their current overall status is 'moderate' (Environment Agency, no date; 2010 data).

The WFD prescribes the use of economic principles to assess the efficiency of water quality improvements. If the costs of restoration exceed the benefits, the costs to achieve the good ecological status might be considered disproportionate and public intervention would not be justified. How much is disproportionate remains a political decision to be taken by Member States and criteria on which to base disproportionality decision varies across countries in Europe (Martin-Ortega, 2012; Martin-Ortega et al., 2014). However, this decision needs to be informed by economic analysis including an assessment of benefits (European Commission, 2003). If peatland restoration is used to help achieving WFD's targets, then benefits of restoration would need to be compared with its costs.

Estimation of the economic benefits from peatland restoration is also relevant in the context of drinking water. Catchment management approaches to improve water quality and meet drinking standards are being put forward (e.g. http://dwi.defra.gov.uk/stake holders/price-review-process/PR14-Position-Statement-CatchmentManagement.pdf). Public authorities and utilities have an interest in understanding the economic efficiency of such approaches, by comparing the costs of land interventions with conventional treatment costs. For example, UK Water Industry Research, which comprises 21 water and sewerage undertakers in the UK, released 
a framework for assessing water quality catchment management initiatives, which highlighted the need for quantifying the benefits of catchment interventions for water utilities (UKWIR, 2012). In Scotland, Scottish Water is testing alternative approaches to supplement the treatment of water supplies through sustainable land management (http://www.scottishwater.co.uk/about-us/corpora te-responsibility/sustainable-land-management).

Peatland restoration may also play an important role in costeffectively achieving national GHG emission reduction targets, considering the capacity for restoration to reduce losses of fluvial carbon as well as sequester and store atmospheric carbon in actively building peat bogs (Bain et al., 2011). The consideration of ancillary benefits of climate change mitigation, such as those related to water quality improvements, is relevant for the design of land-based mitigation strategies (Glenk and Colombo, 2011a) including peatland restoration (Bonn et al., 2014).

Moreover, there is currently an interest to explore market-based instruments such as Payments for Ecosystem Services (PES) schemes, to preserve or improve the supply of ecosystem services in general, and specifically in relation to peatlands (Reed et al., 2014b; Bonn et al., 2014; Whitfield et al., 2011). PES initiatives provide rewards to ecosystem managers for maintaining or improving the provision of services and are advocated in situations in which an environmental externality (e.g. deteriorated water quality due to the drainage of peatlands for agriculture) can be re-dressed through the creation of ad-hoc markets (e.g. payments to farmers for giving up drainage). PES schemes are currently explored as policy instruments to reduce the financial burden of WFD compliance to the public budget (Hirst et al., 2012). There is now evidence across Europe that the costs of complying with the WFD are going to be borne mostly by land managers in rural areas, while benefits are likely to be higher for urban residents (Bateman, 2011). PES-like approaches are being suggested as compensation mechanisms to address this distributional asymmetry (see, for example, the PES research pilots promoted by the UK Department of Environment, Food and Rural Affairs: http://ecosystemsknowledge.net/resources/programmes/pes-pilots/). PES schemes are said have a number of advantages over command and control approaches (Engel et al., 2008), but concerns have been raised, for example regarding the long-term impacts of commodification of nature (Corbera and Pascual, 2012; Kosoy and Corbera, 2010; Ioris, 2010). A critical discussion of PES is beyond the scope of this paper. However, as outlined above, policy attention for PES is increasing, and an important aspect for the design of wellfunctioning PES is knowledge about whether the value of the ecosystem services provided can compensate the opportunity costs for land managers.

\section{The economic value of water quality improvements from peatland restoration}

Water related benefits of peatland restoration can be determined by assessing the change in social welfare ('value') associated with the change in the water status (e.g. change from degraded to restored peatland). Under the predominant neoclassical economic paradigm, the value of a change in water status is based upon individual preferences and measured by the extent to which individuals are willing to trade-off scarce means (such as income) to secure that change. This is most often measured using the concept of willingness to pay (WTP) (Pearce and Turner, 1990). In some special cases, WTP can be derived from market prices for natural resources. However, there are many goods and services that are not traded in markets. For such goods and services, nonmarket valuation techniques have been developed that are referred to as revealed and stated preferences methods (Bateman et al., 2002). Briefly, in revealed preference methods, individual
WTP is observed through actual consumer behaviour that is associated with the non-market good or service being valued, such as through travel behaviour to recreational sites that vary in environmental conditions; or through behaviour in the property market, where price differentials can be linked to improved environmental conditions. Stated preference methods observe consumer behaviour in hypothetical markets created by the researcher; typically, surveys are used to directly ask people to state their WTP for hypothetical states-of-the world or 'scenarios' of improvements in environmental status.

The monetary assessment of the values that society places upon natural resources and the environment has been explored for decades, but it is rapidly evolving around the notion of ecosystem services following the release of the Millennium Ecosystem Assessment (2005). Under an ecosystem services-based approach, the first step for valuation is to identify what is termed final ecosystem services, i.e. the contributions that ecosystems make to human well-being (Fisher et al., 2009; UK NEA, 2011; CICES, 2012). These services are final in that they are the outputs of ecosystems that most directly affect the well-being of people. A fundamental characteristic is that they retain a connection to the underlying ecosystem functions, process and structures that generate them (CICES, 2012, p. 9). The second step for valuation is to translate these final ecosystem services into the goods and benefits that are perceived and valued by people.

\subsection{Final water quality related ecosystem services from peatland restoration}

The Millennium Ecosystem Assessment defined ecosystem services as 'the benefits that people obtain from ecosystems' and established four categories of services (provisioning, regulating, cultural and supporting). Alternative definitions and classifications have emerged since (Boyd and Banzhaf, 2007; Fisher et al., 2009; UK NEA, 2011; CICES, 2012). For practical purposes, in this paper we adopt the classification proposed by the Common International Classification of Ecosystem Services (CICES, 2012).

Based on evidence on peatland restoration outlined in Section 2, Table 1 presents potential effects of peatland restoration on final ecosystem services using the CICES classification. This implies a translation of the changes in the chemical/biological of parameters of water quality that represent outcomes of ecosystem processes (e.g. DOC, FPOM, metals) into the final ecosystem services as the end-products of nature that directly or in combination with manmade capital impact on human well-being.

The above classification requires some elaboration, especially regarding the consideration of provisioning services. Peatlands per se do not supply water, but they have an effect on the delivery of water supply through the ecosystem processes that influence run-off into downstream waters including those used for drinking water supply: e.g. DOC production results in coloured water and peat erosion increases suspended sediment. Peatland restoration can reduce the DOC production and hence the colouring of the water, reducing the negative effect over drinking water as provisioning service.

The identification of cultural ecosystem services also requires explanation. Water quality is part of the wider environment that is associated with cultural ecosystem services. In Table 1 we try to identify the physical, intellectual and symbolic interactions with the ecosystem that are related to water quality (that is why, for example, we do not include 'scientific palaeoecological records, for which peatlands are hugely important sources, but which do not relate directly to water quality). For some final cultural ecosystem services, water quality cannot easily be separated from the surrounding landscape or setting, for example, sense of place and artistic representation emanates from a landscape as a whole 
Table 1

Potential effects of peatland restoration on water quality related final ecosystem services.

Source: Authors' own elaboration using CICES classification of final ecosystem services. Class type not included for simplicity.

\begin{tabular}{|c|c|c|c|c|}
\hline Section & Division & Group & Class & Examples of final ecosystem services \\
\hline \multirow[t]{2}{*}{ Provisioning } & Nutrition & Water & $\begin{array}{l}\text { Surface water for } \\
\text { drinking }\end{array}$ & $\begin{array}{l}\text { - Reduced DOC concentrations and associated reduced } \\
\text { colouration of drinking water (reduced treatment costs) }\end{array}$ \\
\hline & Materials & Water & $\begin{array}{l}\text { Surface water for non- } \\
\text { drinking purposes }\end{array}$ & $\begin{array}{l}\text { Reduced suspended sediments, FPOM and colour in } \\
\text { water abstracted for domestic (non-drinking) and } \\
\text { industrial use (e.g. whisky industry) }\end{array}$ \\
\hline \multirow[t]{4}{*}{$\begin{array}{l}\text { Regulation and } \\
\text { maintenance }\end{array}$} & $\begin{array}{l}\text { Mediation of waste, toxics and other } \\
\text { nuisances }\end{array}$ & $\begin{array}{l}\text { Mediation by } \\
\text { ecosystems }\end{array}$ & $\begin{array}{l}\text { Filtration/ } \\
\text { sequestration/storage/ } \\
\text { accumulation by } \\
\text { ecosystems }\end{array}$ & $\begin{array}{l}\text { - Increased storage of toxic metals and pollutants } \\
\text { ensuring favourable conditions for aquatic biota and } \\
\text { reducing risk to human health }\end{array}$ \\
\hline & Mediation of flows & Mass flows & $\begin{array}{l}\text { Mass stabilization and } \\
\text { control of erosion rates }\end{array}$ & $\begin{array}{l}\text { Reduced suspended sediment loads resulting in less } \\
\text { transport and release of toxic metals and pollutants, } \\
\text { ensuring favourable conditions for aquatic biota, } \\
\text { reducing risk to human health and reducing water } \\
\text { treatment costs. } \\
\text { - Reduced reservoir infilling from erosion and sediment } \\
\text { transport, enhancing water supply capacity for drinking } \\
\text { water and abstraction }\end{array}$ \\
\hline & \multirow[t]{2}{*}{$\begin{array}{l}\text { Maintenance of physical, chemical, } \\
\text { biological conditions }\end{array}$} & $\begin{array}{l}\text { Lifecycle } \\
\text { maintenance, } \\
\text { habitat and gene } \\
\text { pool protection }\end{array}$ & $\begin{array}{l}\text { Maintaining nursery } \\
\text { populations and } \\
\text { habitats }\end{array}$ & $\begin{array}{l}\text { Reduced suspended sediment deposition leading to } \\
\text { increased benthic invertebrate diversity and enhanced } \\
\text { headwater and downstream habitats supporting } \\
\text { commercial and recreational fish populations (e.g. } \\
\text { salmonids) }\end{array}$ \\
\hline & & Water conditions & $\begin{array}{l}\text { Chemical condition of } \\
\text { freshwaters }\end{array}$ & $\begin{array}{l}\text { - Buffering of chemical composition (acidity) of } \\
\text { freshwaters through reduction of atmospherically } \\
\text { derived nitrogen and sulphur to ensure favourable living } \\
\text { conditions for downstream aquatic biota }\end{array}$ \\
\hline \multirow[t]{5}{*}{ Cultural } & \multirow[t]{2}{*}{$\begin{array}{l}\text { Physical and intellectual interactions } \\
\text { with biota, ecosystems, and } \\
\text { landscapes [environmental settings] }\end{array}$} & $\begin{array}{l}\text { Physical and } \\
\text { experiential } \\
\text { interactions }\end{array}$ & $\begin{array}{l}\text { Experiential and } \\
\text { physical use of plants, } \\
\text { animals and } \\
\text { landscapes }\end{array}$ & $\begin{array}{l}\text { - Water quality suitable for recreation activities } \\
\text { downstream (e.g. swimming) }\end{array}$ \\
\hline & & $\begin{array}{l}\text { Intellectual and } \\
\text { representative } \\
\text { interactions } \\
\text { Spiritual, } \\
\text { emblematic }\end{array}$ & $\begin{array}{l}\text { Scientific, educational, } \\
\text { heritage, cultural, } \\
\text { entertainment, } \\
\text { aesthetic }\end{array}$ & $\begin{array}{l}\text { - Water quality suitable to enable preservation of cultural } \\
\text { heritage and to serve as a basis for water-based } \\
\text { educational activities } \\
\text { - Water quality related effects on ex situ viewing/ } \\
\text { experience of natural world through different media, } \\
\text { sense of place, and artistic representations of nature }\end{array}$ \\
\hline & \multirow{3}{*}{$\begin{array}{l}\text { Spiritual, symbolic and other } \\
\text { interactions with biota, ecosystems, } \\
\text { and landscapes [environmental } \\
\text { settings] }\end{array}$} & \multirow{3}{*}{$\begin{array}{l}\text { Spiritual and/or } \\
\text { emblematic } \\
\text { Other cultural } \\
\text { outputs }^{\text {a }}\end{array}$} & Symbolic & $\begin{array}{l}\text { - Water quality suitable for supporting emblematic plants } \\
\text { and animals and stimulating spiritual identity (e.g. }\end{array}$ \\
\hline & & & $\begin{array}{l}\text { Sacred and/or } \\
\text { religious }^{\mathrm{a}}\end{array}$ & Scottish Highlands) \\
\hline & & & Existence and bequest $^{\mathrm{a}}$ & $\begin{array}{l}\text { Water quality suitable to preserve plants, animals, } \\
\text { ecosystems and landscapes for the experience and use } \\
\text { of future generations }\end{array}$ \\
\hline
\end{tabular}

\footnotetext{
a Merged into one group or class for the sake of space.
}

and not strictly to water quality alone. Moreover, and as recognized in CICES, all services, whether they are provisioning or regulating can have a cultural dimension that is difficult to separate (e.g. reduced suspending sediment deposition leading to increased benthic invertebrate diversity could be related to the willingness to preserve natural components of the ecosystem for existence or bequest values). CICES recommends to regard cultural services as the physical settings, locations or situations that give rise to changes in the physical or mental states of people, and whose character are fundamentally dependent on living process (CICES, 2012, p. iv).

As stated above, the identification of final ecosystem services is just a first step for valuation, which should focus on the actual goods and benefits derived from those final ecosystem services as perceived and valued by the public. CICES (2012, p. i) defines ecosystem goods and services as the 'things that people create or derive from final ecosystem services', i.e. the final outcomes from ecosystem services turned into products or experiences that are not functionally connected to the systems from which they derive (CICES refers to goods and services collectively as 'products'). Goods and benefits should be identified on a case-by-case basis. This is because the specific nature of the goods and benefits associated with peatland restoration is highly dependent on the local context. For example, not all water bodies downstream of a restored peatland will support commercial fisheries. Benefits arising from reduced suspension of sediments and FPOM in water abstracted for industrial use clearly depend on the type of industry affected: a greater level of suspended sediments and FPOM will be acceptable for agricultural abstraction, but cause issues for the beverage industry (e.g., Scotch malt whisky). 
In the next sections we discuss how the valuation of goods and benefits of peatland restoration could be approached based on the existing experience in the valuation literature. For the sake of clarity, we have split the discussion into two sections: the first one looks at financial (market) benefits and the second section discusses the wider economic (non-market) benefits of peatland restoration. It should be noted that the benefits described in the next sections are not simply additive. After, we discuss the key challenges for valuing these benefits.

\subsection{Valuing peatland restoration's financial (market) benefits}

In terms of benefits, reduced production of DOC relates to improved quality of drinking water. To meet drinking water quality standards set out in the European Drinking Water Directive, DOC has to be removed from drinking water supplies, as otherwise chlorination during water treatment results in the production of potentially harmful disinfection bi-products (Singer, 1999). Water colour is a major water treatment issue for water utility companies, because removal of colour imposes a direct cost. UK water utilities have experienced increasing difficulties with DOC levels in the past years (Sharp et al., 2006), and are facing increasing costs of more sophisticated treatment process, such as coagulation, adsorption and membrane filtration. According to Whitehead et al. (2006), DOC removal represents the single largest cost to water utilities in the UK. Land management such as peatland restoration can potentially both prevent further increases in water colour and reduce water colour associated with peat degradation (see Section 2.2). Reduced colouration from peatland restoration then has a direct financial benefit for the utilities in the form of reduced treatment costs.

While the valuation of this benefit might seem straightforward, two main challenges arise. Firstly, data availability from water utility companies is restricted due to confidentiality issues. Our review of the scientific and grey literature found no published data. Secondly, recent research suggests DOC is sensitive to other drivers such as climate change effects (UKWIR, 2011) and reductions in atmospheric sulphur deposition (Monteith et al., 2007; see Section 2.2). The former report, for example, concludes that 'DOC is set to increase [due to climate change], with an associated increase in colour. This may significantly increase treatment costs, energy and carbon, and lead to higher risk of disinfection byproduct formation. This projected change will mainly impact direct filtration plants and use of chlorine disinfection' (p. 8). Therefore, potential DOC improvements associated with peatland restoration might be affected by climate change or atmospheric deposition impacts, and the estimation of benefits associated with restoration rely on an accurate assessment of such climate change and atmospheric deposition impacts under restoration and business as usual conditions.

A further potential benefit of restoration relates to commercial fishing, through enhanced headwater and downstream habitats supporting fish populations associated with the reduction in suspended sediment loads and acidity (Steinberg and Wright, 1994; Bilotta and Brazier, 2008). In theory, these benefits could be assessed by looking at the increased revenues of commercial or recreational fisheries downstream. However, the benefits of peatland restoration to fish populations have not been fully quantified and there are not yet data demonstrating improvements in fisheries following restoration. There are models that link water pollution to impacts of fish species in terms of risk coefficients, but such outputs have yet to be given a meaningful interpretation in terms of (potential) changes in fish populations in a certain study area, so that the benefits to commercial fisheries can be soundly estimated.

\subsection{Valuing the wider economic (non-market) benefits of peatland restoration}

As shown in Table 1, many of the services potentially enhanced or secured by peatland restoration are regulating and cultural ecosystem services. Some aspects of cultural ecosystem services can be associated with markets (e.g. fees for recreational fishing), but for most of them there are no markets in which the goods (or experiences) are traded. Similarly, there are no markets for (most of) these regulating services.

Stated preference methods are suitable for assessing non-market benefits related to both use values (e.g., swimming, recreational fishing) and non-use values (e.g., knowledge of the existence of salmonid fish in a river) of improved ecological status of water bodies. In stated preferences studies, a hypothetical market is constructed that consists of one or several states of the world (also called valuation scenarios) defined in terms of expected improvements in an ecosystem's (ecological) status that can be obtained at a cost to the individual, and a state of the world that emerges without an additional intervention to improve an ecosystem's status but has no extra cost associated with it (also called the status quo scenario). Typically in a survey setting, individuals are then asked to express their preferences for the alternative improvement scenarios (including the status quo), thereby stating their WTP for an improvement. The development of these scenarios is crucial to the valuation process, and requires researchers to develop an appropriate explanation and description of the level of ecosystem services provision with and without an intervention. On the one hand, the scenarios need to be rigorous in terms of ecosystem services delivery that is underpinned by sound science. On the other hand, they have to be credible and understandable by the general public who is asked to express its preferences (Barkmann et al., 2008; Kataria et al., 2012).

The valuation of non-market benefits associated with most of the final ecosystem services identified in Table 1 could draw on the wealth of experience gathered in previous studies aimed at estimating the benefits of achieving good ecological status in water bodies, emerged following on the implementation of the WFD. Hanley et al. (2006) used three river quality attributes: in-stream ecology (salmon presence and vegetation, birds and insects), aesthetics/appearance (sewage and litter presence) and bank-side conditions (bank vegetation and erosion levels). Subsequent studies have used different forms of the so-called 'water quality ladder', which describes water quality on an ascending scale of water-use possibilities (ranging from 'boatable', 'fishable' to 'swimmable'), as proposed by Carson and Mitchell (1993) for the implementation of the USA Clean Water Act. The ladder of water use categories has been used extensively to assess benefits of the good ecological status of water bodies, e.g. Baker et al. (2007), Del-Saz-Salazar et al. (2009), Brouwer et al. (2010), Glenk et al. (2011), Bateman et al. (2011), Ramajo-Hernandez and Del-Saz-Salazar (2012), Metcalfe et al. (2012), Schaafsma et al. (2012, 2013), and Perni et al. (2012). In these studies, description of status categories and possible recreational and other uses were accompanied by figures and imagery depicting ecological components to highlight additional (non-use) values (e.g. habitat modification, river flow rate, fish life, aquatic vegetation, river bank vegetation, substrate composition and water clarity) and supporting texts understandable to the general public. Similar status categorizations could be, in principle, adapted and used for assessment of non-market benefits of peatland restoration, but challenges arise, as discussed next.

\section{Discussion of challenges for the valuation of benefits from peatlands restoration}

The main challenges for the valuation of water quality related benefits from peatland restoration can be clustered around the 
following key issues:

(1) the availability of evidence on effects of peatland restoration in terms of final ecosystem services and how these translate into goods and benefits that are perceived and valued by the public;

(2) the temporal and spatial processes and relationships affecting peatlands' response to restoration;

(3) how to relate cultural ecosystem services to peatlands and peatland features per se, and not to access to recreation (e.g. existence of paths) or to aesthetic and symbolic values associated with the broader landscape (e.g., Scottish Highlands) rather than peatlands specifically.

Challenge (3) basically represents a direct research question that can be best addressed through quantitative or qualitative research techniques, such as participatory mapping and deliberative processes, to reflect the spatial context in which cultural ecosystem services emerge (e.g. van Berkel and Verburg, 2014; Plieninger et al., 2013; Kenter et al., 2014). In the remainder of this section, we therefore focus on challenges (1) and (2).

\subsection{Availability of evidence on effects of peatland restoration in terms of final ecosystem services and how these translate into goods and benefits that are perceived and valued by the public}

There is a need to translate the underpinning science on water ecology impacts into valuation scenarios that are meaningful to the public and can be used for the elicitation of their preferences and values. The general public will find it extremely difficult if not impossible to value changes in metal loads, suspended sediments, acidity, DOC or FPOM from peatland restoration, even if these affect their well-being. There is hence a gap between the typical outputs of ecological and hydrological models, which may provide changes in these ecological indicators and parameters, and the translation of such changes in goods and benefits that people value. As mentioned, a first step requires the identification of final ecosystem services, which we have attempted generically in Table 1 and which can give a first indication of the types of goods and benefits that may arise from peatland restoration, e.g. drinking water, reduced risk of human health, enhanced water supply, commercial fish populations, etc. The water quality 'ladder' or categorization approach as discussed in Section 4.3 can help convey how peatland restoration is related to changes in water related ecosystem services and associated goods and benefits. However, for the use of such water quality ladders in peatland valuation, the categories of the ladder need to be solidly linked to restoration. Firm evidence is not yet available for all potential effects of peatland restoration on water quality (as described in Section 2), and therefore for all the final ecosystem services and associated benefits. There is a natural science challenge to gather further evidence on these effects, but social science input is also required to ensure the ladder enables lay respondents to make informed decisions, particularly in relation to regulating ecosystem services. Some regulating services represent final 'products' themselves (e.g. increased storage of toxic metals reducing risk to human health), while others serve as inputs (intermediary services) for the generation of products (e.g. reduced sediment deposition leading to improved habitat for biota can relate to cultural ecosystem services associated with existence or bequest values of wildlife). How people understand these regulating services and relate them to their well-being needs to be better understood.

\subsection{Temporal and spatial processes and relationships affecting peatlands' restoration reaction}

The available evidence suggests that most peatland restoration benefits occur downstream. Firstly, reduction of suspended sediment concentration, acidification and metal concentration in the headwater systems would indirectly benefit downstream ecosystems, for example, in relation to fish recruitment from upland spawning sites. Secondly, the majority of the people often live in the downstream areas of river catchments. Therefore, improvement of headwater systems leading to increased quality of drinking water and reduced treatment costs would mostly benefit consumers downstream (Van der Wal et al., 2011). Capturing spatial heterogeneity of preferences of environmental values is now good environmental valuation practice (Schaafsma et al., 2012), and is achieved through, for example, measuring how values decay with distance (see Glenk et al., 2014). Addressing the spatial distribution of the benefits of peatland restoration is then, in principle, possible with current valuation instruments. However, ecological effects of water quality changes depend on the ecosystem in which these changes take place, so even when water quality changes are similar in terms of chemical or nutrient loads, the resulting ecological status and the associated goods and services can be different and may require a different description for different locations in the valuation survey (Schaafsma et al., 2013). For example, after restoration, DOC concentrations will be influenced by declining aerobic DOC production (which will decrease DOC). In systems with high historical atmospheric sulphur loadings, however, DOC concentrations following restoration will also be influenced by suppression of sulphate (which will increase DOC; see Section 2.2). As a result, peatlands with high sulphate levels from acid deposition might behave differently to those where acid deposition has historically been lower. The potential of peatlands to provide final ecosystem services after restoration may thus differ across locations, meaning that generic valuation ladders might not be applicable across the board.

Furthermore, while some ecological improvements may occur fairly rapidly after restoration ( $<5$ years, e.g. suspended sediments and FPOM), others may be subject to a significant time lag (colour, acidity, metals). This may have implications for the valuation of benefits arising from ecological improvements. In general, WTP values have a time dimension as people prefer shortterm over longer-term benefits, and are, for example, willing to pay more for an improvement occurring next year than for a similar improvement in 10 years time (see Glenk et al., 2014). Moreover, there are also differences across social groups. For example, Viscusi et al. (2008) find that visitors to rivers and lakes not only place greater values on water quality improvements than non-visitors, but also are more willing to tolerate delays in improvements.

\section{A way forward}

Evidence for the impacts of peatland restoration on water quality is still emerging. There is strong evidence of rapid $(<5$ years) responses of suspended sediments and associated ecological condition; and there is sufficient evidence to expect that rewetting will prevent further declines in water quality in the longer term. However, when trying to value the benefits of these effects, two major types of challenges arise: (1) incomplete evidence of effects of peatland restoration on final ecosystem services and their translation into goods and benefits, and (2) the spatial and temporal differences in peatlands' responses to restoration. The ultimate consequence of these difficulties in the understanding of the ecosystem is uncertainty about the specific benefits of 
peatland restoration and, hence, the challenge on how to deal with that uncertainty in valuation. This requires interdisciplinary research into the bio-physical processes associated with peatland restoration and ecosystem services delivery and the way these are valued by the public. Yet, there is a need to incorporate these values into current decision-making processes, such as the assessment of whether the costs of achieving good ecological status under the WFD would be disproportionality high, and for the establishment of economic instruments such as PES.

As an immediate way forward, we suggest developing valuation scenarios on a case-by-case basis, based on best available evidence of the changes associated with restoration in some form of peatland status ladder or categorization, similar to the ladders of ecological status developed for the WFD. Such status ladders would need to be tested with the public, for example using of participatory techniques, to ensure that specific goods and benefits can be meaningfully defined, particularly in relation to changes in regulating and cultural ecosystem services. The valuation scenarios should include an element of uncertainty in ecosystems provision. This has been done before in the valuation literature, for example, in the context of atmospheric contamination (see Wielgus et al., 2009 for a review), climate change mitigation (Glenk and Colombo, 2011b) and water supply (Rigby et al., 2010; Mesa-Jurado et al., 2012). In such studies, the public is asked about their WTP for an environmental outcome that is delivered with a degree of uncertainty. Respondents can simply be informed prior to valuation that the outcome which they are asked to pay for is uncertain. Uncertainty can be also introduced by including a probabilistic element in the valuation scenario, for example, by associated a certain environmental with a certain probability or presenting uncertainty in terms of risk of failure of the mitigation action. These or similar approaches could be applied in the context of stated preferences for the valuation of water quality improvements from peatland restoration. While such approaches are associated with methodological difficulties (Glenk and Colombo, 2013), outcome-related uncertainty cannot be ignored in the context of valuing water related ecosystem service delivery following peatland restoration.

\section{Acknowledgements}

This work has been developed within the Valuing Nature Network project "Valuing Peatlands: Assessing and valuing peatland ecosystem services for sustainable management" funded by the Natural Environment Research Council (UK). All project participants are to be thanked for their contribution to discussions from which this paper has nourished. Special thanks to Aletta Bonn and Chris Evans for their coordinating role, as well as to Mark Reed who also provided valuable comments to an earlier version of this paper. Special thanks to Vikki Hirst for the organization of the Joint water@leeds and IUCN-Valuing Nature Network Workshop on Catchment management using payments for ecosystem services to restore and maintain upland peat, which led to fruitful discussions reflected in this paper. The work of Dr. Martin-Ortega has been co-financed by the Scottish Government through its Centre of Expertise Climate Change: Mitigation-Peatland Restoration Project and the Rural Affairs and the Environment Portfolio Strategic Research Programme 2011-2016, Theme 1 (Environmental Change: Ecosystem Services and Biodiversity). The work by Dr. Glenk has been co-financed by 'SmartSOIL (Grant Agreement No. 289694) co-funded by the European Commission, Directorate General for Research \& Innovation, within the 7th Framework Programme of RTD, Theme 2 - Biotechnologies, Agriculture \& Food'. Dr. Allott acknowledges the support of Moors for the Future and associated funding from DEFRA and the Environment Agency. Authors are grateful to Rebekka Artz for continued support.

\section{References}

Acreman, M., 2001. Ethical aspects of water and ecosystems. Water Policy 3, $257-265$.

Anderson, P., Buckler, M., Walker, J., 2009. Moorland restoration: potential and progress. In: Bonn, A., Allott, T., Hubacek, K., Stewart, J. (Eds.), Drivers of Environmental Change in Uplands. Routledge, London, pp. 432-447.

Anderson, P., Worrall, P., Ross, S., Hammond, G., Keen, A., 2011. United Utilities sustainable catchment management programme. Vol. 2: Restoring drained, burned and grazed moorlands. Report to United Utilities by Penny Anderson Associates. Available from/http://corporate.unitedutilities.com/scamp-monitor ing-reports.aspx $>$ (accessed 22.08.12).

Armstrong, A., Holden, J., Kay, P., Francis, B., Foulgar, M., Gledhill, S., McDonald, A.T., Walker, A., 2010. The impact of peatland drain-blocking on dissolved organic carbon loss and discolouration of water: results from a national survey. J. Hydrol. 381, 112-120.

Bain, C.G., Bonn, A., Stoneman, R., Chapman, S., Coupar, A., Evans, M., Gearey, B., Howat, M., Joosten, H., Keenleyside, C., Labadz, J., Lindsay, R., Littlewood, N., Lunt, P., Miller, C.J., Moxey, A., Orr, H., Reed, M., Smith, P., Swales, V., Thompson, D.B.A., Thompson, P.S., Van de Noort, R.,Wilson, J.D.,Worrall,F., 2011. IUCN UK Commission of Inquiry on Peatlands. IUCN UK. Peatland Programme, Edinburgh.

Baker, B., Metcalfe, P., Butler, S., Gueron, Y., Sheldon, R., East, J., 2007. Report on the Benefits of Water Framework Directive Programmes of Measure in England and Wales. DEFRA, United Kingdom.

Barkmann, J., Glenk, K., Keil, A., Leemhuis, C., Dietrich, N., Gerold, G., Marggraf, R., 2008. Confronting unfamiliarity with ecosystem functions: the case for an ecosystem service approach to environmental valuation with stated preference methods. Ecol. Econ. 65, 48-62.

Bateman, I.J., 2011. Catchment Hydrology, Resources, Economics and Management: Integrated Modelling of WFD Impacts upon Rural Land Use and Farm Incomes. End of Award Report. 〈http://www.cserge.ac.uk/sites/default/files/110616\%20-\% 20ChREAM\%20Project\%20Report\%20-\%20Revised.pdf〉( accessed June 2014).

Bateman, I.J., Carson, R.T., Day, B., Hanemann, M., Hanley, N., Hett, T., Jones-Lee, M., Loomes, G., Mourato, S., Özdemiroglu, E., Pearce, D.W., Sugden, R., Swanson, J., 2002. Economic Valuation with Stated Preference Techniques A manual. Edward Elgar Publishing, Cheltenham.

Bateman, I.J., Brouwer, R., Ferrini, S., Schaafsma, M., Barton, D.N., Dubgaard, A., Hasler, B., Hime, S., Liekens, I., Navrud, S., 2011. Making benefit transfers work: deriving and testing principles for value transfers for similar and dissimilar sites. Environ. Resour. Econ. 50 (3), 365-387.

Bilotta, G.S., Brazier, R.E., 2008. Understanding the influence of suspended solids on water quality and aquatic biota. Water Res. 42, 2842-2861.

Black, J., Milner-Gulland, E.J., Sotherton, N., Mourato, S., 2010. Valuing complex environmental goods: landscape and biodiversity in the North Pennines. Environ. Conserv. 37 (2), 136-146.

Bonn, A., Holden, J., Parnell, M., Worrall, F., Chapman, P.J., Evans. C.D., Termansen, M., Beharry-Borg, N., Acreman, M.C., Rowe, E., Emmett, B., Tsuchiya, A., 2010. Ecosystem services of peat - Phase 1. DEFRA Project code: SP0572.

Bonn, A. Reed, M.S., Bain, C. Joosten, H., Farmer, J., Evans, C., Artz, R., Glenk, K., Smith, P., Emmer, I., Couwenberg, J., Worrall, F., Holden, J., 2014. Investing in nature: developing ecosystem service markets for peatland restoration. Ecosyst. Serv. 9, 54-65.

Boyd, J., Banzhaf, S., 2007. What are ecosystem services? The need for standardized environmental accounting units. Ecol. Econ. 63 (2-3), 616-626.

Brouwer, R., Martin-Ortega, J., Berbel, J., 2010. Spatial preference heterogeneity: a choice experiment. Land Econ. 863, 552-568.

Carson, R.T., Mitchell, R., 1993. The value of clean water: the public's willingness to pay for boatable, fishable and swimmable quality water. Water Resour. Res. $297,2445$.

CICES - Common International Classification of Ecosystem Services, 2012. Consultation on Version 4, August-December 2012. EEA Framework Contract No EEA/IEA/09/003. 〈http://cices.eu/ (last accessed 05.06.14).

Clarke, J.M., Chapman, P.J., Adamson, J.K., Lane, S.N., 2005. Influence of droughtinduced acidification on the mobility of dissolved organic carbon in peat soils. Glob. Change Biol. 11, 791-809.

Clarke, J.M., Bottrell, S.H. Evans, C.D., Monteith, D.T., Bartlett, R., Rose, R. Newton, R.J., Chapman, P.J., 2010. The importance of the relationship between scale and process in understanding long-term DOC dynamics. Sci. Total Environ. 408, 2768-2775.

Corbera, E., Pascual, U., 2012. Ecosystem services: heed social goals. Science 335 (10), 355-356.

Daniels, S.M., Evans, M.G., Agnew, C.T., Allott, T.E.H., 2008. Sulphur leaching from headwater catchments in an eroded peatland, South Pennines, UK. Sci. Total Environ. 407, 481-496.

Daniels, S.M., Evans, M.G., Agnew, C.T., Allott, T.E.H., 2012. Ammonium release from a blanket peatland into headwater stream systems. Environ. Pollut. 163, 261-272.

Del-Saz-Salazar, S., Hernández-Sancho, F., Sala-Garrido, R., 2009. The social benefits of restoring water quality in the context of the Water Framework Directive: a comparison of willingness to pay and willingness to accept. Sci. Total Environ. 407 (16), 4574-4583.

Drake, B., Smart, J., Termansen, M., Hubacek, K., 2013. Public preferences for production of local and global ecosystem services. Reg. Environ. Change J. 13 (3), 649-659. 
Engel, S., Pagiola, S., Wunder, S., 2008. Designing payments for environmental services in theory and practice: an overview of the issues. Ecol. Econ. 65 (4), 663-674.

Environment Agency, no date. Water Framework Directive - Surface Water Classification Status and Objectives. Available from 〈www.data.gov.uk/data sets/wfd-surface-water-classification-status-and-objectives $\rangle$ (last accessed 23.05.14).

European Commission, 2003. Economics and the Environment: The Implementation Challenge of the 21 Water Framework. Directive - WATECO: A Guidance Document. EC, Brussels.

Evans, M.G., Warburton, J., Yang, J., 2006. Sediment budgets for eroding blanket peat catchments: global and local implications of upland organic sediment budgets. Geomorphology 79, 45-57.

Evans, M.G., Warburton, J., 2007. Geomorphology of Upland Peat: Erosion, Form and Landscape Change. Blackwell, Oxford.

Evans, M.G., Pawson, R., Daniels, S, Yang, J., Wilkinson, R., 2009. Monitoring carbon flux from moorland restoration sites. Report to Natural England and Moors. Upland Environments Research Unit, University of Manchester, 36 pp.

Evans, C.D., Bonn, A., Holden, J., Reed, M.S., Worrall, F., Evans, M., Glenk, K., Parnell, M., et al., 2014. Relationships between anthropogenic pressures and ecosystem functions in UK blanket bogs: linking process understanding to ecosystem service valuation. Ecosyst. Serv. 9, 5-19.

Fisher, B., Turner, K.R., Morling, P., 2009. Defining and classifying ecosystem services for decision making. Ecol. Econ. 68 (3), 643-653.

Gibson, H.S., Worrall, F., Burt, T.P., Adamson, J.K., 2009. DOC budgets of drained peat catchments: implications for DOC production in peat soils. Hydrol. Processes 23, 1901-1911.

Glenk, K., Colombo, S., 2011a. Designing policies to mitigate the agricultural contribution to climate change: an assessment of soil based carbon sequestration and its ancillary effects. Clim. Change 105, 43-66.

Glenk, K., Colombo, S., 2011b. How sure can you be? A framework for considering delivery uncertainty in benefit assessments based on stated preference methods. J. Agric. Econ. 62 (1), 25-46.

Glenk, K., Lago, M., Moran, D., 2011. Public preferences for water quality improvements: implications for the implementation of the EC Water Framework Directive in Scotland. Water Policy 13 (5), 645-662.

Glenk, K., Colombo, S., 2013. Modelling outcome-related risk in choice experiments. Aust. J. Agric. Resour. Econ. 57 (4), 559-578.

Glenk, K., Schaafsma, M., Moxey, A., Martin-Ortega, J., Hanley, N., 2014. Valuing peatland restoration for spatially targeted ecosystem service delivery. Ecosyst. Serv. 9, 20-33, http://dx.doi.org/10.1016/j.ecoser.2014.04.007.

Hanley, N., Wright, R., Álvarez-Farizo, B., 2006. Estimating the economic value of improvements in river ecology using choice experiments: an application to the Water Framework Directive. J. Environ. Manag. 78, 183-193.

Hirst, V., Bain, C., Bonn, A., Evans, C., Glenk, K., Holder, J., Martin-Ortega, J., Reed, M., 2012. Catchment management using payments for ecosystem services to restore and maintain upland peat. Joint water@leeds and IUCN-Valuing Nature Network Workshop 09.05.12. Available at: 〈http://www.wateratleeds.org/ uploads/files/Peat\%20PES\%20Briefing\%20Note.pdf . (last accessed 16.01.13).

Holden, J., Chapman, P.J., Labadz, J.C., 2004. Artificial drainage of peatlands: hydrological and hydrochemical process and wetland restoration. Prog. Phys. Geogr. 28, 95-123.

Holden, J., Gascoign, M., Bosanko, N.R., 2007. Erosion and natural revegetation associated with surface land drains in upland peatlands. Earth Surf. Process. Landf. 32, 1547-1557.

Ioris, A., 2010. The political nexus between water and economics in Brazil: a critique of recent policy reforms. Rev. Radic. Polit. Econ. 42 (2), 231-250.

Janssen, R., Goosen, H., Verhoeven, M.L., Verhoeven, J.T., Omtzigt, A.Q.A., Maltby, E., 2005. Decision support for integrated wetland management. Environ. Model. Softw. 20 (2), 215-229.

Kataria, M., Bateman, I.J., Christensen, T., Dubgaard, A., Hasler, B., Hime, S. Ladenburg, J., Levin, G., Martinsen, L., Nissen, C., 2012. Scenario realism and welfare estimates in choice experiments - a non-market valuation study on the European water framework directive. J. Environ. Manag. 94 (1), 25-33.

Kenter, J.O., Reed, M.S., Irvine, K.N., O’Brien, E., Brady, E., Bryce, R., Christie, M., Church, A., Cooper, N., Davies, A., Hockley, N., Fazey, I., Jobstvogt, N., Molloy, C., Orchard-Webb, J., Ravenscroft, N., Ryan, M., Watson, V., 2014. UK National Ecosystem Assessment Follow-on phase, Technical report: Shared, Plural and Cultural Values of Ecosystems. UNEP-WCMC, Cambridge.

Kosoy, N., Corbera, E., 2010. Payments for ecosystem services as commodity fetishism. Ecol. Econ. 69, 1228-1236.

Maltby, E., Ormerod, S.J., 2011. Freshwaters-openwaters, wetlands and floodplains. The UK National Ecosystem Assessment Technical Report. UNEP-WCMC, Cambridge, pp. 295-360.

Martin-Ortega, J., 2012. Economic prescriptions and policy applications in the implementation of the European Water Framework Directive. Environ. Sci. Policy 24, 83-91.

Martin-Ortega, J., Skuras, D., Perni, A., Holen, S., Psaltopoulos, D., 2014. The disproportionality principle in the WFD: how to actually apply it?. In: Bournaris, T., Berbel, J., Manos, B., Viaggi, D. (Eds.), Economics of Water Management in Agriculture. Science Publishers.

Mesa-Jurado, A., Martin-Ortega, J., Berbel, J., Ruto, E., 2012. The economic value of guaranteed water supply for irrigation under scarcity conditions. Agric. Water Manag. 113, 10-18.

Metcalfe, P.J., Baker, W., Andrews, K., Atkinson, G., Bateman, I.J., Butler, S., Carson, R. T., East, J., Gueron, Y., Sheldon, R., Train, K., 2012. An Assessment of the
Nonmarket Benefits of the Water Framework Directive for Households in England and Wales,. Water Resources Research, 48, W03526, 18 pp.

Millennium Ecosystem Assessment, 2005. Ecosystems and Human Well-being: Current State and Trends. Island Press, Washington, DC.

Monteith, D.T., Stoddard, J.D., Evans, C.D., de Wit, H.A., Forsius, M., Høgåsen, T. Wilander, A., Skjelkvåle, B.L., Jeffries, D.S., Vuorenmaa, J., Keller, B., Kopácek, J. Vesely, J., 2007. Dissolved organic carbon trends resulting from changes in atmospheric deposition chemistry. Nature 450, 537-541.

Parry, L.E., Holden, J., Chapman, P.J., 2014. Restoration of blanket peatlands. J. Environ. Manag. 133, 193-205.

Pearce, D., Turner, R.K., 1990. Economics of Natural Resources and the Environment Pearson Education Ltd., Essex.

Perni, A., Martinez-Paz, J., Martinez-Carrasco, F., 2012. Social preferences and economic valuation for water quality and river restoration: the Segura River Spain. Water Environ. J. 26, 274-284.

Plieninger, T., Dijks, S., Oteros-Rozas, E., Bieling, C., 2013. Assessing, mapping and quantifying cultural ecosystem services. Land Use Policy 33, 118-129.

Ramajo-Hernandez, J., Del-Saz-Salazar, S., 2012. Estimating the non-market benefits of water quality improvement for a case study in Spain: a contingent valuation approach. Environ. Sci. Policy 22, 47-59.

Ramchunder, S.J., Brown, L.E., Holden, J., 2009. Environmental effects of drainage, drain-blocking and prescribed vegetation burning in UK upland peatlands. Prog. Phys. Geogr. 33 (1), 49-79.

Ramchunder, S.J., Brown, L.E., Holden, J., 2012. Catchment-scale peatland restoration benefits stream ecosystem biodiversity. J. Appl. Ecol. 49, 182-191.

Reed, M.S., Bonn, A., Evans, C., Glenk, K., Hansjurgens, B., 2014a. Editorial: assessing and valuing peatland ecosystem services for sustainable management. Ecosyst. Serv. 9, 1-4.

Reed, M., Moxey, A., Prager, K., Hanley, N., Skates, J., Bonn, A., Evans, C.D., Glenk, K., Thomson, K., 2014b. Improving the link between payments and the provision of ecosystem services in agri-environment schemes in UK peatlands. Ecosyst. Serv. 9, 44-53.

Rigby, D., Alcon, F., Burton, M., 2010. Supply uncertainty and the economic value of irrigation water. Eur. Rev. Agric. Econ. 37 (1), 97-117.

Rothwell, J.J., Evans, M.G., Daniels, S.M., Allott, T.E.H., 2008. Peat soils as a source of lead contamination to upland fluvial systems. Environ. Pollut. 153, 582-589.

Rothwell, J.J., Taylor, K.G., Chenery, S., Cundy, A., Evans, M.G., Allott, T.E.H., 2010 Storage and behavior of $\mathrm{As}, \mathrm{Sb}, \mathrm{Pb}$ and $\mathrm{Cu}$ in omrotrophic peat bogs under contrasting water table conditions. Environ. Sci. Technol. 44, 8497-8502.

Rydin, H., Jeglum, J.Y., 2006. The Biology of Peatlands. Oxford University Press, Oxford.

Schaafsma, M., Brouwer, R., Rose, J., 2012. Directional heterogeneity in WTP models for environmental valuation. Ecol. Econ. 79, 21-31.

Schaafsma, M., Brouwer, R., Gilbert, A., van den Bergh, J.C.J.M., Wagtendonk, A., 2013. Estimation of distance-decay functions to account for substitution and spatial heterogeneity in stated preference research. Land Econ. 89 (3), 514-537.

Sharp, E.L., Parsons, S.A., Jefferson, B., 2006. Seasonal variations in natural organic matter and its impact on coagulation in water treatment. Sci. Total Environ. 363, 183-194.

Singer, P.C., 1999. Humic substances as precursors for potentially harmful disinfection by-products. Chemosphere 54, 1017.

Steinberg, C.E.W., Wright, R.F., 1994. Acidification of freshwater ecosystems: implications for the future. Bioscience 45, 4 .

Strange, N., Jacobsen, J.G., Thorsen, B.J., Tarp, P., 2007. Value for money: protecting endangered species on Danish Heathland. Environ. Manag. 40 (5), 761-774.

Trepel, M., 2010. Assessing the cost-effectiveness of the water purification function of wetlands for environmental planning. Ecol. Complex. 7 (3), 320-326.

UK NEA - UK National Ecosystem Assessment, 2011. The UK National Ecosystem Assessment: Synthesis of the Key Findings. UNEP-WCMC, Cambridge.

UKTAG - UK Technical Advisory Group on the Water Framework Directive, 2007. Recommendations on surface water classification schemes for the purposes of the water framework directive. Available from $\langle$ www.wfduk.org $\rangle$ (last accessed 23.05.14)

UKWIR - UK Water Industry Research, 2011. CL08B201 - Climate Change Implications for Water Treatment Interim Report on the likely changes in water quality due to climate change, April 2011.

UKWIR - UK Water Industry Research, 2012. Quantifying the benefits of water quality catchment management initiatives. 1-84057-648-0. 〈http://www.ukwir. org/ukwirlibrary/95165).

United Utilities, 2010. SCaMP Sustainable Catchment Management Programme Monitoring Progress Report Year 4. Penny Anderson Associates Ltd. 〈http:/ www.unitedutilities.com/SCaMPdatalibrary.aspx $>$.

van Berkel, D.B., Verburg, P.H., 2014. Spatial quantification and valuation of cultura ecosystem services in an agricultural landscape. Ecol. Indic. 37, 163-174.

Van der Wal, R., Bonn, A., Monteith, D., Reed, M., Blackstock, K., Hanley, N., Thompson, D., Evans, M., Alonso, I, Allott, T., Armitage, H., Beharry, N., Glass, J., Johnson, S., McMorrow, J., Ross, L., Pakeman, R., Perry, S., Tinch, D., 2011. Mountains, Moorlands and Heaths. UK National Ecosystem Assessment. The UK National Ecosystem Assessment Technical Report. UNEP-WCMN, Cambridge pp. 105-159.

Viscusi, W.K., Huber, J., Bell, J., 2008. Estimating discount rates for environmenta quality from utility-based choice experiments. J. Risk Uncertain. 37, 199-220.

Wallage, Z.E., Holden, J., McDonald, A.T., 2006. Drain blocking: an effective treatment for reducing dissolved organic carbon loss and water discolouration in a drained peatland. Sci. Total Environ. 367, 811-821. 
Wichtmann, W., Wichmann, S., 2011. Environmental, social and economic aspects of a sustainable biomass production. J. Sustain. Energy Environ. 77, 81 (special issue).

White, P.C.L., Lovett, J.C., 1999. Public preferences and willingness-to-pay for nature conservation in the North York Moors National Park, UK. J. Environ. Manag. 55 (1), 1-13.

Whitehead, P., Futter, M., Wilby, R., 2006. Impacts of climate change on hydrology, nitrogen and carbon in upland and lowland streams: assessment of adaptation strategies to meet Water Framework Directive objectives. In: Proceedings of BHS 9th National Hydrology Symposium, Durham.

Whitfield, S., Reed, M., Thomson, K., Christie, M., Stringer, L.C., Quinn, C.H., Anderson, R., Moxey, A., Hubacek, K., 2011. Managing peatland ecosystem services: current UK policy and future challenges in a changing world. Scott. Geogr. J. 127 (3), 209-230.

Wielgus, J., Gerber, L.R., Sala, E., Bennett, J., 2009. Including risk in statedpreference economic valuations: experiments on choices for marine recreation. J. Environ. Manag. 90, 3401-3409.

Wilson, L., Wilson, J., Holden, J., Johnstone, I., Armstrong, A., Morris, M., 2011. Ditch blocking, water chemistry and organic carbon flux: evidence that blanket bog restoration reduces erosion and fluvial carbon loss. Sci. Total Environ. 409, 2010-2018.

Worrall, F., Armstrong, A., Holden, J., 2007. Short-term impact of peat drainblocking on water colour, dissolved organic carbon concentration, and water table depth. J. Hydrol. 337, 315-325. 